\title{
BioLink
}

JURNAL BIOLOGI LINGKUNGAN, INDUSTRI, KESEHATAN

Available online http://ojs.uma.ac.id/index.php/biolink

\section{PENGARUH KADAR ASAM SULFAT PADA HIDROLISIS TANDAN KOSONG KELAPA SAWIT (TKS) DAN WAKTU FERMENTASI TERHADAP KADAR BIOETANOL YANG DIHASILKAN}

\section{The effect of sulphuric acid fermentation of processed palm oil bunch hydrolysis and on ethanol and sugar production}

\author{
Sartini ${ }^{1}$, Rita Fitriani ${ }^{2}$, Rosliana ${ }^{3}$ \\ 1Fakultas Biologi Universitas Medan Area, 2Pusat Penelitian Kelapa Sawit Medan, \\ ${ }^{3}$ Fakultas Biologi Universitas Medan Area \\ *Corresponding author: E-mail: 60stnurcahya@gmail.com
}

\begin{abstract}
Abstrak
Pengaruh kadar asam sulfat pada hidrolisis tandan kosong kelapa sawit (tks) dan waktu fermentasi terhadap kadar bioetanol yang dihasilkan telah dilakukan. Tujuannya penelitian adalah untuk mengetahui kemampuan hidrolisis optimum oleh Saccharomyces cerevisiae untuk menghasilkan bioetanol dan gula. Sebanyak 12,5 g serbuk kelapa sawit bekas digunakan dalam percobaan ini. Bubuk tersebut beberapa kali dihidrolisis dengan asam sulfat dalam beberapa variasi konsentrasi. Produksi gula terdeteksi setiap satu jam dengan menggunakan spektrofotometer. Gula difermentasi oleh Saccharomyces cerevisiae dan diinkubasi selama beberapa hari. Hasil penelitian menunjukkan bahwa konsentrasi asam sulfat 2-4\% merupakan konsentrasi oprimum untuk produksi gula 30 g / L. Produksi etanol tertinggi 4,94\% terjadi setelah dua hari fermentasi.
\end{abstract}

Kata kunci: asam sulfat, fermentasi, bioethanol, Saccharomyces cerevisiae

\begin{abstract}
The effect of sulphuric acid fermentation of processed palm oil bunch hydrolysis and on ethanol and sugar production was conducted. The aim was to investigate the hydrolytic optimum required by Saccharomyces cerevisiae for ethanol and sugar production. About $12.5 \mathrm{~g}$ powdered palm oil bunch was used in this experiment. The powder was hydrolized several times using sulphuric acid in several concentration. Sugar, product of hydrolysis, was detected every one hour using spectrophotometer. The sugar was fermented by Saccharomyces cerevisiae and incubated for several days. Results showed that 2-4\% sulphuric acid was oprimum concentration for $30 \mathrm{~g} / \mathrm{L}$ sugar production. The highest ethanol production $4.94 \%$ occurred after two days fermentation.
\end{abstract}

Keywords: sulphuric acid, fermentation, ethanol, Saccharomyces cerevisiae

How to Cite: Fitriani, R. Sartini. Rosliana, 2018, Pengaruh Kadar Asam Sulfat pada Hidrolisis Tandan Kosong Kelapa Sawit (TKS) dan Waktu Fermentasi terhadap Kadar Bioetanol yang Dihasilkan, BioLink, Vol. 4 (2): Hal. 154-161 


\section{PENDAHULUAN}

Kelapa sawit merupakan salah satu tanaman penghasil minyak nabati yang sangat penting di sektor pertanian umumnya dan sub sektor perkebunan pada khususnya, karena kelapa sawit merupakan tanaman yang menghasilkan minyak nabati terbesar sekitar 3-7 ton minyak nabati perhektar pertahun. Minyak ini dapat diperoleh dari dua jenis minyak yaitu minyak serabut (mesocarp) dan minyak inti sawit (endosperm) (Ditjenbun, 2004).

Sisa atau limbah dari pengolahan minyak kelapa sawit ini adalah limbah padat dan limbah cair. Limbah padat yang tidak dimanfaatkan salah satu nya adalah tandan kosong kelapa sawit. Tandan kosong kelapa sawit (TKS) adalah limbah padat berlignoselulosa yang belum termanfaatkan secara optimal. Selama ini pemanfaatan tandan kosong hanya sebagai bahan bakar boiler, kompos dan juga sebagai pengeras jalan di perkebunan kelapa sawit. Padahal tandan kosong kelapa sawit berpotensi untuk dikembangkan menjadi barang yang lebih berguna, salah satunya menjadi bahan baku bioetanol. Hal ini karena tandan kosong kelapa sawit banyak mengandung selulosa yang dapat dihirolisis menjadi glukosa kemudian difermentasi menjadi bioetanol.

TKS adalah salah satu limbah padat pabrik kelapa sawit yang dihasilkan dari proses pengolahan tandan buah segar (TBS) dengan jumlah 22-23\% TKS. Pada tahun 1994 jumlah TKS yang dihasilkan sebanyak 12,4 juta ton dengan asumsi bahwa 1 Ha kebun menghasilkan 20 ton TBS. Karena mengandung 45,95 \% selulosa, 22,84\% hemiselulosa, 16,49\% lignin, 1,23\% abu, 0,53 \% nitrogen dan 2,41\% minyak maka TKS berpotensi sebagai bahan baku bioetanol (Darnoko, 1992).

Fermentasi merupakan kegiatan mikroba pada bahan pangan sehingga dihasilkan produk yang dikehendaki. Mikroba yang umumnya telibat dalam fermentasi adalah bakteri, khamir dan kapang. Contoh bakteri yang digunakan dalam fermentasi adalah Acetobacter xylimnum pada pembuatan nata de coco, Acetobacter aceti pada pembuatan asam asetat. Contoh khamir dalam fermentasi adalah Saccharomyces cerevisiae dalam pembuatan alkohol. Prinsip dasar fermentasi adalah mengaktifkan kegiatan mikroba tertentu untuk tujuan mengubah sifat bahan, agar dapat dihasilkan sesuatu yang bermanfaat. Misalnya asam dan alkohol yang dapat mencegah pertumbuhan mikroba yang beracun (Widayati, 1996).

Awalnya fermentasi merupakan proses pemecahan gula menjadi alkohol dan karbondioksida. Tetapi banyak proses yang dikatakan fermentasi tidak selalu menggunakan substrat gula dan menghasilkan alkohol serta karbondioksida, contohnya perubahan laktosa menjadi asam laktat oleh bakteri Streptococcus lactis pada kondisi anaerobik. Hasil-hasil fermentasi terutama tergantung pada jenis substrat, macam mikroba dan kondisi di sekelilingnya yang mempengaruhi pertumbuhan dan metabolisme mikroba tersebut (Winarno,1980).

Bioetanol merupakan salah satu biofuel yang hadir sebagai bahan bakar alternative yang lebih ramah lingkungan dan sifatnya yang terbarukan. Pada umumnya pembuatan bioetanol 
menggunakan jagung dan tebu sebagai bahan baku. Penggunaan kedua bahan baku tersebut bepotensi menimbulkan kontradiksi terhadap kebutuhan bahan pangan bila diterapkan di Negara berkembang seperti Indonesia. Oleh sebab itu, selulosa berpotensi menjadi salah satu bahan baku alternatifnya dan Tandan Kosong Kelapa Sawit (TKS) memiliki potensi yang besar menjadi sumber biomassa selulosa dengan kelimpahan cukup tinggi dan sifatnya terbarukan (Dea, 2009).

Bahan baku untuk proses produksi bioetanol diklasifikasikan menjadi tiga kelompok, yaitu gula, pati, dan selulosa. Sumber gula yang berasal dari gula tebu, gula bit, molase dan buah-buahan, dapat langsung dikonversi menjadi etanol. Sumber dari bahan berpati seperti jagung, singkong, kentang dan akar tanaman harus dihidrolisis terlebih dahulu menjadi gula. Sumber selulosa yang berasal dari kayu, limbah pabrik pulp dan kertas, semuanya harus dikonversi menjadi gula dengan bantuan asam mineral. Biokonversi glukosa menjadi bioetanol, memerlukan perantara mikroba lain yang umumnya menggunakan Saccharomyces cereviceae dan Zymonas mobilis. Beberapa hal penting yang perlu diketahui pada proses produksi bioetanol antara lain, komponen ligniselulosa dan enzim pendegradasinya (Trisanti, 2009).

Bioetanol secara umum dapat digunakan sebagai bahan baku industri turunan alkohol, campuran bahan bakar untuk kendaraan. Grade bioetanol harus berbeda sesuai dengan pengunaanya. Bioetanol yang mempunyai grade 90\% -
96,5\% volume digunakan pada industri, grade $96 \%$ - 99,5\% digunakan dalam campuran untuk miras dan bahan dasar industri farmasi. Besarnya grade bioetanol yang dimanfaatkan sebagai campuran bahan bakar untuk kendaraan harus betul-betul kering dan anhydrous supaya tidak menyebabkan korosi, sehingga bioetanol harus mempunyai grade sebesar 99,5\% - 100\% (Khairani, 2007).

Bioetanol yang digunakan
sebagai bahan bakar mempunyai
beberapa kelebihan, diantaranya lebih ramah lingkungan, karena bahan bakar tersebut memiliki nilai oktan 92 lebih tinggi dari premium nilai oktan 88 , dan pertamax nilai oktan 94. Hal ini membuat bioetanol dapat menggantikan fungsi zat aditif yang sering ditambahkan untuk memperbesar nilai oktan. Zat aditif yang banyak digunakan seperti metal tersier butil eter dan $\mathrm{Pb}$, namun zat aditif tersebut sangat tidak ramah lingkungan dan bisa bersifat toksik. Bioetanol juga merupakan bahan bakar yang tidak mengakumulasi gas karbon dioksida $\left(\mathrm{CO}_{2}\right)$ dan relatif kompetibel dengan mesin mobil berbahan bakar bensin. Kelebihan lain dari bioetanol ialah cara pembuatannya yang sederhana yaitu fermentasi menggunakan mikroorganisme tertentu (Mursyidin, 2007).

\section{METODE PENELITIAN}

Rancangan Penelitian

Penelitian ini menggunakan RSM untuk optimasi proses. RSM merupakan teknik matematika dan statistika yang berguna untuk pemodelan dan analisa masalah dimana responnya dipengaruhi 
oleh beberapa variable yang tujuannya untuk mengoptimalkan respon tersebut. Adapun metode RSM meliputi: perancangan percobaan, pengembangan model matematis dan penentuan kondisi optimum untuk variabel bebas sehingga diperoleh hasil maksimum dan minimum dari proses hidrolisis TKS menggunkan asam sulfat untuk menghasilkan bioetanol. Langkah awal dari desain RSM adalah menentukan perkiraan yang sesuai untuk relasi fungsi yang tepat antara respon dan variabel bebas. Dengan metode RSM diperoleh persamaan polynomial kuadratik yang dapat digunakan untuk memperkirakan hasil dari fungsi variabel bebas serta interaksinya.

Tabel 1. Kode level untuk hidrolisis TKS

\begin{tabular}{|c|c|c|c|c|}
\hline No. & $\begin{array}{c}\text { Kode kadar } \\
\text { asam }\end{array}$ & $\begin{array}{c}\text { Kode } \\
\text { waktu }\end{array}$ & $\begin{array}{c}\text { Kadar } \\
\text { asam } \\
(\%)\end{array}$ & $\begin{array}{c}\text { waktu } \\
\text { (jam) }\end{array}$ \\
\hline 1 & $-1,00000$ & $-1,00000$ & 4 & 2 \\
\hline 2 & $-1,00000$ & 1,00000 & 4 & 8 \\
\hline 3 & 1,00000 & $-1,00000$ & 8 & 2 \\
\hline 4 & 1,00000 & 1,00000 & 8 & 8 \\
\hline 5 & $-1,41421$ & 0,00000 & 3,17 & 5 \\
\hline 6 & 1,41421 & 0,00000 & 8,83 & 5 \\
\hline 7 & 0,00000 & $-1,41421$ & 6 & 0,76 \\
\hline 8 & 0,00000 & 1,41421 & 6 & 9,24 \\
\hline 9 & 0,00000 & 0,00000 & 6 & 5 \\
\hline 10 & 0,00000 & 0,00000 & 6 & 5 \\
\hline
\end{tabular}

Proses hidrolisis TKS

Ditimbang serbuk TKS produksi PPKS sebanyak 12,5 g dimasukkan ke dalam Erlenmeyer $500 \mathrm{ml}$, lalu ditambahkan $250 \quad \mathrm{~mL}_{2} \mathrm{H}_{2} \mathrm{SO}_{4} \quad 2 \quad \%$. Dilakukan perlakuan yang sama untuk konsentrasi asam 0\% (sebagai kontrol), 4\%, 6\% , 8\% dan $10 \%$, ditutup dengan kapas dan aluminium foil, lalu dihidrolisis dalam autoklaf pada suhu $121^{\circ} \mathrm{C}$ selama 0 jam(sebagai kontrol), 1 , $2,3,4,5,6,7$, dan 8 jam lalus didinginkan. Sebanyak $1 \mathrm{ml}$ filtrat yang diperoleh dari tiap jam proses dilakukan pengenceran, lalu dimasukkan ke dalam tabung reaksi dan dianalisa kadar gula dengan menggunakan metode spektrofotometri. Perlakuan dilakukan 2 ulangan.

\section{Proses Pembuatan Etanol}

Larutan gula yang dihasilkan dari proses hidrolisis TKS sebanyak $1500 \mathrm{ml}$ ditambah larutan $\mathrm{NaOH}$ 50\% sampai $\mathrm{pH}$ 5, lalu ditambahkan 50 g yeast extract, $83,33 \mathrm{~g}$ pepton from meat, $25 \mathrm{ml}$ media fermentasi mikro nutrisi, selanjutnya homogenkan. Dimasukkan sebanyak 90 $\mathrm{ml}$ kedalam masing-masing botol fermentasi disterilisasi dengan menggunakan autoklaf pada suhu $121^{\circ} \mathrm{C}$ selama 15 menit lalu didinginkan. Ditambahkan Saccharomyces serevisiae sebanyak 2 gram ke dalam botol yang berisi larutan gula, kemudian diinkubasi pada suhu kamar selama 0 hari, 1 hari, 2 hari, 3 hari, 4 hari, dan 5 hari. Setiap perlakuan dilakukan 2 ulangan.

\section{Analisa Produk}

Produk terdiri dari dua macam yaitu gula hasil hidrolisis TKS dan bioetanol hasil fermentasi. Analisa Produk dilakukan dengan metoda spektrofotometri dan metoda SNI 012892-1992

1. Penentuan kadar gula dengan metoda spektrofotometer

Produk hasil hidrolisis berupa gula yang dianalisa mengunakan metode spektrofotometri. Sebanyak $2 \mathrm{ml}$ sampel dimasukkan ke dalam tabung reaksi, lalu ditambahkan $3 \mathrm{~mL}$ larutan DNS setelah itu panaskan di atas penangas selama 10 menit. Setelah 
larutan dingin diukur absorbansinya pada panjang gelombang $580 \mathrm{~nm}$.

Kadar gula dapat dihitung dengan persamaan kurva kalibrasi larutan standar gula. Setiap perlakuan dilakukan 2 ulangan

2. Penentuan kadar alkohol dengan metoda SNI 01-2892-1992

Kadar alkohol ditentukan setelah fermentasi berlangsung dengan melakukan destilasi. Dipipet $50 \mathrm{ml}$ sampel dan dimasukkan ke dalam labu destilasi lalu ditambahkan akuades dengan volume yang sama, pada penampung alkohol dengan piknometer dimasukkan $2 \mathrm{ml}$ akuades. Campuran dipanaskan sampai mendidih $80^{\circ} \mathrm{C}$ kemudian didestilasi sehingga didapatkan hasil destilasi $23 \mathrm{ml}$. Setiap perlakuan dilakukan 2 ulangan. Hasil destilasi ditimbang dalam piknometer dan bobot jenis alkohol dapat ditentukan dengan rumus:

$$
\mathrm{BJ}=\frac{\mathrm{B} 1-\mathrm{B} 0}{\mathrm{~B} 2-\mathrm{B} 0}
$$

Keterangan:

BJ (Bobot jenis hasil destilasi)

B0 (Bobot piknometer kosong)

B1 (Bobot piknometer kosong ditambah bobot hasil destilasi)

B2 (Bobot piknometer kosong ditambah bobot air)

\section{HASIL DAN PEMBAHASAN}

\section{Pengaruh Lama Fermentasi terhadap Kadar Bioetanol}

Kadar bioetanol tertinggi dari fermentasi gula hasil hidrolisis yang

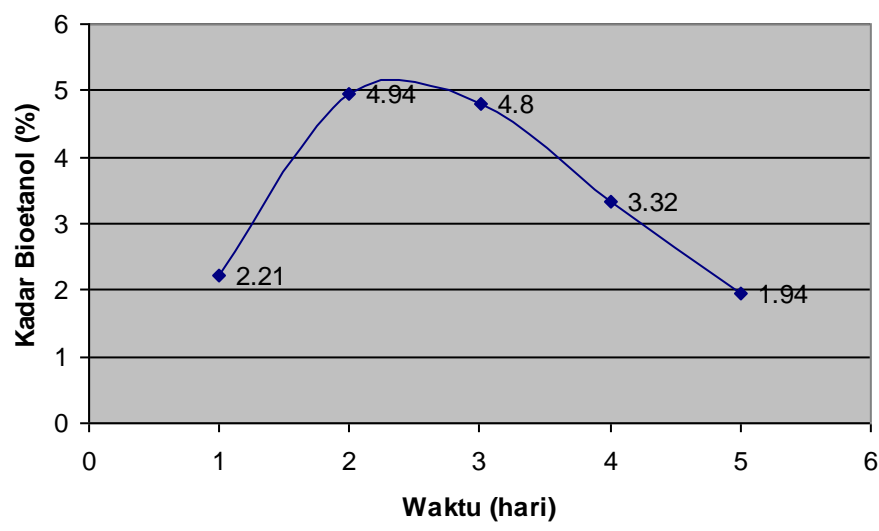

Gambar 1. Pengaruh lama fermentasi gula hasil hidrolisis TKS oleh Saccharomyces cerevisiae terhadap kadar bioetanol

Penurunan kadar etanol terjadi setelah difermentasikan selama 3 hari sampai 5 hari. Hal ini dikarenakan mikroba yang berperan dalam fermentasi telah memasuki fase kematian (fase penurunan) yang diakibatkan oleh kondisi media telah berkurang (substrat dan nutrient habis) sehingga banyak sel yang tidak mampu membelah dan berkembangbiak lagi (Black, 1999).

Khamir Saccharomyces cerevisiae memiliki siklus pertumbuhan yang sama dengan bakteri, pada khamir setelah melewati fase adaptasi, pertumbuhan logaritma, dan stationer (tetap) juga akan mengalami fase kematian. Adapun sebab kematiannya adalah karena zat makanan yang diperlukan menjadi berkurang, sehingga bakteri mengalami fase kematian, selain itu hasil ekskresi 
bakteri itu sendiri terakumulasi pada medium pertumbuhan, sehingga mengganggu pembiakan dan pertumbuhan (Heru, 1994).

$$
\text { Menurut Muljono }
$$

penurunan ini juga dapat disebabkan oleh terjadinya oksidasi dari etanol menjadi asetaldehid dan selanjutnya dioksidasi lagi menjadi asam asetat, sehingga akan mengakibatkan media fermentasi semakin asam.

\section{Pengaruh Waktu Hidrolisis dan Kadar Asam Sulfat terhadap Kadar Gula}

Pengaruh waktu dan kadar asam sulfat terhadap kadar gula dilakukan pada 9 level waktu berbeda, yaitu 1 sampai 8 jam dan 0 jam (sebagai kontrol). Percobaan dilakukan pada kondisi reaksi asam sulfat 2, 4, 6, 8, 10 dan $0 \%$ (tanpa asam sulfat sebagai kontrol) pada konsentrasi TKS 50 gram/Liter.

Hidrolisis yang mengunakan asam sulfat dengan konsentrasi $2 \%, 4 \%, 6 \%$, $8 \%$ dan $10 \%$, perolehan gula meningkat hingga waktu 4 jam, tetapi pada saat waktu ditambah hingga 8 jam kadar gula yang dihasilkan menurun. Sedangkan pada waktu lebih rendah (1 - 4 jam) menunjukkan proses pembentukan gula terus meningkat. Hal ini menunjukkan bahwa peningkatan waktu akan mempengaruhi pembentukan produk gula.

Hidrolisis tanpa asam sulfat tidak menunjukkan terjadinya pembentukan gula karena untuk memecah TKS menjadi selulosa diperlukan katalis asam pada reaksi waktu tertentu. Kadar Asam sulfat yang memberikan pengaruh terbesar pada pembentukan gula dilihat dari Tabel 2. adalah pada kondisi kadar asam sulfat $2 \%$, dengan kadar gula 24,64 gram/liter.

Menurut Judoamidjojo (1989), hidrolisis pati dengan asam hanya memperoleh glukosa dengan ekivalen dektrosa (DE) sebesar 55, hal ini disebabkan katalis asam hanya menghidrolisis secara acak.

Konversi asam dan waktu reaksi yang terlalu lama untuk membuat glukosa hingga DE diatas 55 bisa menyebabkan molekul gula itu bergabung kembali dan menghasilkan bahan pembentuk warna seperti hidroksimetil 5- furfural atau asam levulinat.

Tabel 2. Pengaruh waktu hidrolisis TKS dan kadar asam sulfat terhadap kadar gula yang dihasilkan.

\begin{tabular}{ccccccc}
\hline \multirow{2}{*}{$\begin{array}{c}\text { WAKTU } \\
\text { HIDROLISIS }\end{array}$} & \multicolumn{6}{c}{ KADAR GULA (GRAM/LITER) } \\
\cline { 2 - 7 } (JAM) & 0 & 2 & 4 & 6 & 8 & 10 \\
\hline 0 & 0 & 0 & 0 & 0 & 0 & 0 \\
1 & 0 & 18.84 & 21.52 & 20.68 & 18.41 & 16.81 \\
2 & 0 & 22.04 & 22.31 & 22.31 & 19.15 & 15.94 \\
3 & 0 & 22.2 & 23.04 & 18.57 & 22.94 & 15.83 \\
4 & 0 & 24.62 & 22.4 & 17.88 & 16.89 & 15.44 \\
5 & 0 & 24.46 & 21.46 & 17.36 & 16.52 & 15.41 \\
6 & 0 & 23.78 & 20.99 & 16.88 & 15.83 & 14.99 \\
7 & 0 & 23.04 & 20.89 & 16.81 & 15.78 & 14.81 \\
8 & 0 & 22.41 & 18.57 & 16.8 & 15.44 & 14.68 \\
\hline
\end{tabular}




\section{Optimasi Proses}

Optimasi proses dilakukan dengan mengunakan aturan rancangan percobaan central composite design (CCD), sehingga diperoleh 10 run percobaan. Penelitian ini memilih CCD sebagai bentuk desain ekperimen disebabkan oleh CCD memberikan rancangan yang sistematik untuk memperoleh interaksi antar variabel. Dari rancangan CCD ini akan diperoleh interaksi dari kedua variable yaitu waktu hidrolisis ( $\left.\mathrm{X}_{1}\right)$ dan kadar Asam sulfat $\left(\mathrm{X}_{2}\right)$. Percobaan optimasi yang telah dilakukan terdapat pada Tabel 3 di bawah ini.

Tabel 3. Hasil percobaan optimasi pengaruh waktu hidrolisis dan kadar asam sulfat terhadap kadar gula

\begin{tabular}{ccccc}
\hline $\begin{array}{c}\text { Kode } \\
\text { kadar } \\
\text { asam }\end{array}$ & $\begin{array}{c}\text { Kode } \\
\text { waktu }\end{array}$ & $\begin{array}{c}\text { Kadar } \\
\text { asam } \\
(\%)\end{array}$ & jam & $\begin{array}{c}\text { Kadar gula } \\
\text { (gram/Liter) }\end{array}$ \\
\hline $\begin{array}{c}- \\
1,00000\end{array}$ & $\begin{array}{c}1,00000 \\
-\end{array}$ & 4 & 2 & 22.31 \\
1,00000 & 1,00000 & 4 & 8 & 18.7 \\
1,00000 & - & & 2 & 19.15 \\
1,00000 & 1,00000 & 8 & & \\
- & 0,00000 & 8 & 8 & 15.44 \\
1,41421 & 0,000 & 3,17 & 5 & 24.54 \\
1,41421 & 0,00000 & 8,83 & 5 & 16.07 \\
0,00000 & - & 6 & 0,76 & 20.17 \\
0,00000 & 1,41421 & & & \\
0,00000 & 0,00000 & 6 & 5 & 17.36 \\
0,00000 & 0,00000 & 6 & 5 & 17,00 \\
\hline
\end{tabular}

Pengaruh Kadar Asam Sulfat dan Waktu Hidrolisis terhadap Kadar Gula

Hasil analisis Anova CCD pada Lampiran 5 menunjukkan bahwa kadar asam sulfat dan waktu hidrolisis berpengaruhi signifikan (R-squared 0,93 dan $p$-value $<0,05$ ) terhadap kadar gula yang terbentuk. Kadar asam sulfat dan waktu hidrolisis berpengaruh baik secara linier. Estimasi efek faktor terhadap kadar gula diperoleh secara matematis :

$$
\begin{aligned}
& Y=17,18-2,99 X_{1}-1,519 X_{2}+1,441 X_{1}^{2} \\
& +0,519 X_{2}^{2}-0,025 X_{1} X_{2}
\end{aligned}
$$

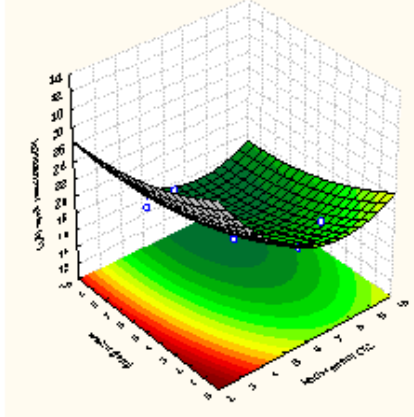

Gambar 2. Permukaan respon tanggap perolehan kadar gula terhadap variasi kadar asam sulfat dan waktu hidrolisis

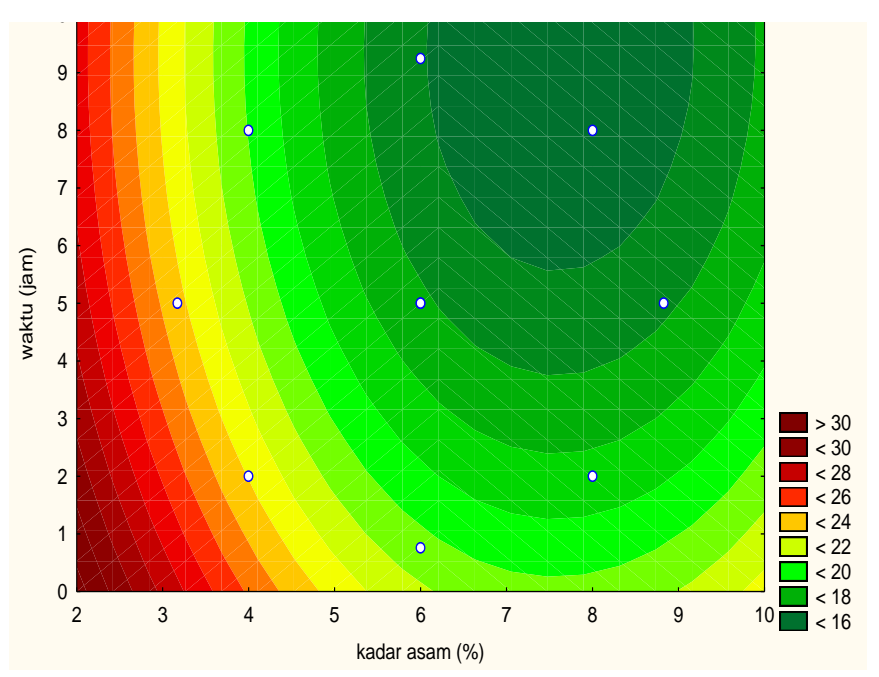

Gambar 3. Plot kontur kadar asam sulfat terhadap waktu hidrolisis

Gambar 2 dan 3 menunjukkan respon dan plot kontur dari hasil analis 
permukaan tanggap menunjukkan bahwa titik optimum perolehan gula (lebih dari 30 gram/liter) diperoleh kadar asam 2 sampai 4\% dan waktu kecil dari 4 jam. Titik minimum terbentuknya kadar gula berada pada kadar asam 8 \% dan waktu 8 jam.

\section{SIMPULAN}

Berdasarkan penelitian yang dilakukan dapat disimpulkan bahwa, kadar asam sulfat yang optimum untuk mendapatkan kadar gula tertinggi adalah $2 \%$ sampai dengan $4 \%$ dan waktu reaksi yang optimum adalah 1 sampai 4 jam, dengan kadar gula sekitar 30 gram/liter. Untuk mendapatkan bioetanol dengan kadar tertinggi diperlukan waktu selama 2 hari dengar kadar 4, $94 \%$.

\section{DAFTAR PUSTAKA}

Black J. G. 1999. Microbiology Principle and Exploration. Prentice Hall. USA

Darnoko. 1992. Potensi Pemanfaatan Limbah Lignoselulosa Kelapa Sawit Melalui Biokonversi. Medan: Berita Penelitian Perkebunan, Vol. 5

Judoamidjojo. 1992. Teknologi Fermentasi. Edisi 1 cetakan 1. Rajawali Press. Jakarta

Khairani, R. 2007. Tanaman Jagung Sebagai Bahan Bio-fuel. UNPAD. Bandung.

Muljono. 1990. Teknologi Fermentasi. Rajawali Press. Jakarta.

Mursyidin, D. 2007. Ubi Kayu dan Bahan Bakar Terbarukan. Banjarmasin.

Widayati, E. 1996. Limbah Untuk Pakan Ternak. Trubus Agrisarana. Surabaya.

Winarno, F. G. 1980.. Kimia Pangan. Gramedia. Jakarta 